\title{
Seasonal and diurnal variations of atmospheric mercury across the US determined from AMNet monitoring data
}

\author{
X. Lan ${ }^{1}$, R. Talbot ${ }^{1}$, M. Castro ${ }^{2}$, K. Perry ${ }^{3}$, and W. Luke ${ }^{4}$ \\ ${ }^{1}$ Institute for Climate and Atmospheric Science, Department of Earth and Atmospheric Sciences, University of Houston, \\ Houston TX 77004, USA \\ ${ }^{2}$ Center for Environmental Science, University of Maryland, Frostburg, MD 21532, USA \\ ${ }^{3}$ University of Utah, Salt Lake City, UT 84112-0110, USA \\ ${ }^{4}$ National Oceanographic and Atmospheric Administration, Air Resources Laboratory, Silver Spring, Maryland 20910, USA
}

Correspondence to: X. Lan (xlan3@uh.edu)

Received: 27 March 2012 - Published in Atmos. Chem. Phys. Discuss.: 26 April 2012

Revised: 8 October 2012 - Accepted: 5 November 2012 - Published: 13 November 2012

\begin{abstract}
Speciated atmospheric mercury observations collected over the period from 2008 to 2010 at the Environmental Protection Agency and National Atmospheric Deposition Program Atmospheric Mercury Network sites (AMNet) were analyzed for its spatial, seasonal, and diurnal characteristics across the US. Median values of gaseous elemental mercury (GEM), gaseous oxidized mercury (GOM) and particulate bound mercury (PBM) at 11 different AMNet sites ranged from $148-226 \mathrm{ppqv}\left(1.32-2.02 \mathrm{ng} \mathrm{m}^{-3}\right)$, $0.05-1.4 \mathrm{ppqv}\left(0.47-12.4 \mathrm{pg} \mathrm{m}^{-3}\right)$ and $0.18-1.5 \mathrm{ppqv}(1.61-$ $\left.13.7 \mathrm{pg} \mathrm{m}^{-3}\right)$, respectively. Common characteristics of these sites were the similar median levels of GEM as well as its seasonality, with the highest mixing ratios occurring in winter and spring and the lowest in fall. However, discernible differences in monthly average GEM were as large as $30 \mathrm{ppqv}$, which may be caused by sporadic influence from local emission sources. The largest diurnal variation amplitude of GEM occurred in the summer. Seven rural sites displayed similar GEM summer diurnal patterns, in that the lowest levels appeared in the early morning, and then the GEM mixing ratio increased after sunrise and reached its maxima at noon or in the early afternoon. Unlike GEM, GOM exhibited higher mixing ratios in spring and summer. The largest diurnal variation amplitude of GOM occurred in spring for most AMNet sites. The GOM diurnal minima appeared before sunrise and maxima appeared in the afternoon. The increased GOM mixing ratio in the afternoon indicated a photochemically driven oxidation of GEM resulting in GOM formation. PBM exhibited diurnal fluctuations in summertime. The summertime
\end{abstract}

PBM diurnal pattern displayed daily maxima in the early afternoon and lower mixing ratios at night, implying photochemical production of PBM in summer.

\section{Introduction}

Mercury is an important environmental pollutant that can enter the food chain and pose threats to ecosystems and human health (EPA, 1997). Atmospheric mercury exists in three different chemical forms that consist of gaseous elemental mercury $\left(\mathrm{GEM}=\mathrm{Hg}^{\circ}\right)$, gaseous oxidized mercury $\left(\mathrm{GOM}=\mathrm{HgCl}_{2}+\mathrm{HgBr}_{2}+\mathrm{HgOBr}+\ldots\right)$ and particular bound mercury (PBM). GEM is reported to be the predominant $(\sim 95 \%)$ atmospheric mercury species (Lindberg and Stratton, 1998,), with a relatively long lifetime (6-24 months) that enables its global transport (Weiss-Penzias et al., 2003). GEM can be oxidized to GOM by hydroxyl radical $(\mathrm{OH})$, nitrate radical $\left(\mathrm{NO}_{3}\right)$, and halogen radicals (Pal and Ariya, 2004a,b; Sommar et al.,2001; Sommar et al., 1997; Laurier et al., 2003; Raofie and Ariya, 2004; Holmes et al., 2006, 2010), part of which can be converted to PBM on aerosol surfaces. GOM and PBM account for a small fraction of atmospheric mercury and are thought to be readily deposited on the order of 1-7 days after they are produced (Valente et al., 2007). The sources of atmospheric mercury consists of various anthropogenic emissions (e.g., coal combustion, waste incineration and transportation) (Seigneur et al., 2004, 2006) and natural sources (e.g., mercury enriched soils, the

Published by Copernicus Publications on behalf of the European Geosciences Union. 
ocean and volcanoes) (Pacyna et al., 2002, 2006, 2010; Sigler et al., 2003; Sigler and Lee, 2006; Brunk et al., 2001; Friedli et al., 2003a, b, 2004, 2011; Ebinghaus et al., 2007), resulting in great diversity in mercury levels around the world.

A recent review by Sprovieri et al. (2010) reported that the current global background concentration of GEM was in the range of 1.5 to $1.7 \mathrm{ng} \mathrm{m}^{-3}(168-190 \mathrm{ppqv})$ in the Northern Hemisphere. Continuous monitoring datasets at two coastal sites in Europe (Mace Head and Zingst) showed that the annually total gaseous mercury $(\mathrm{TGM}=\mathrm{GEM}$ + GOM) concentrations were $1.72 \mathrm{ng} \mathrm{m}^{-3}$ (193 ppqv) at Mace Head and $1.66 \mathrm{ng} \mathrm{m}^{-3}$ (186 ppqv) at Zingst (Kock et al., 2005). Long-term measurements at the Canadian Atmospheric Mercury Measurement Network (CAMNet) reported that the $10 \mathrm{yr}$ averaged TGM concentrations of all CAMNet sites was $1.58 \mathrm{ng} \mathrm{m}^{-3}$ (177 ppqv), slightly lower than European records (Temme et al., 2007). A study in Reno, a city in the western US apparently influenced by regional mining, showed a 3 -yr average GEM value of $1.6 \mathrm{ng} \mathrm{m}^{-3}$ (179 ppqv) and an exceptionally high GOM value of $26 \mathrm{pg} \mathrm{m}^{-3}$ (2.9 ppqv). Distinct seasonality was found, with the highest GEM concentrations in winter and highest GOM concentrations in summer (Peterson et al., 2009). For rural and mountainous sites in northeastern and southeastern US, Sigler and Lee (2006) and Valente et al. (2007) suggested typical levels of GEM were about $1.6 \mathrm{ng} \mathrm{m}^{-3}$ (179 ppqv). In general, the background GEM levels are globally consistent.

The Atmospheric Mercury Network (AMNet) is a longterm monitoring network in the United States aimed at quantifying the ambient levels of speciated mercury across the US. A few published analyses on these sites documented regional mercury levels, mercury sources and its temporal variation. Measurements in a rural area in the Northeast, the Adirondacks of New York State (NY20), showed that the average concentrations of GEM, GOM and PBM were $1.4 \pm 0.4 \mathrm{ng} \mathrm{m}^{-3}(157 \pm 45 \mathrm{ppqv}), 1.8 \pm 2.2 \mathrm{pg} \mathrm{m}^{-3}$ $(0.2 \pm 0.2 \mathrm{ppqv})$ and $3.2 \pm 3.7 \mathrm{pg} \mathrm{m}^{-3}(0.4 \pm 0.4 \mathrm{ppqv})$, respectively (Choi et al., 2008). The urban site in Rochester (NY95) exhibited GEM, GOM and PBM concentrations of $1.49-1.52 \mathrm{ng} \mathrm{m}^{-3}$ (167-170 ppqv), $1.83-8.70 \mathrm{pg} \mathrm{m}^{-3}$ (0.2$1.0 \mathrm{ppqv})$ and $4.70-7.48 \mathrm{pg} \mathrm{m}^{-3}(0.5-0.8 \mathrm{ppqv})$, slightly higher than at the NY20 site (Huang et al., 2010). Melting snow, chemical oxidation, coal fired power plant and mobile emissions during rush hours were identified as important factors influencing speciated mercury variations in Rochester (Huang et al., 2010). Temporal variability of ambient mercury levels reflect the effects of chemical and physical sources and sinks, which are of great importance in understanding regional mercury budgets. Analysis of data obtained at Thompson Farm, a rural AMNet site in New Hampshire (NH06), found noticeable GEM daily patterns in summer and fall with the daily maximum occurring around 10:00 and minimum at 05:00-06:00 Local Standard Time (LST). GOM peaked at midday with seasonal daily maxima ranging from $0.5 \mathrm{ppqv}$ (summer/fall) to $1.6 \mathrm{ppqv}$ (spring) (Sigler et al., 2009). GOM levels at Appledore Island (a marine site near NH06) were higher than at NH06 suggesting the possibility that GEM was oxidized by abundant halogen radicals in the marine environment leading to higher GOM mixing ratios (Mao and Talbot, 2012a). Measurements at a rural site in the Ohio River Valley region (OH02) showed that the GEM diurnal pattern had the highest levels at midday. GOM mixing ratios reached maximum values at noon and then slowly decreased throughout the rest of the day to a minimum at 06:00. Because the GOM maxima coincided with afternoon elevated ozone and temperature, GOM diurnal variation in Ohio may be associated with regional transport of photochemically processed air masses (Yatavelli et al., 2006).

To date there has not been an in-depth analysis across all AMNet sites to document mixing ratios of mercury, and their seasonal and diurnal variability at multiple sites in the US. In-depth comparison of sites is needed for an improved detailed understanding of the distribution on various temporal and spatial scales, and to better inform regional and global models.

\section{Measurements and approach}

\subsection{AMNet sites}

The Atmospheric Mercury Network (AMNet) is one of the monitoring networks in the Environmental Protection Agency and National Atmospheric Deposition Program in the US, designed to provide information on mercury in precipitation, deposition chemistry, and its phase fractionations in ambient air. This network includes more than 20 automated speciated mercury sampling sites, including some cooperating sites outside the US. Continuous measurement data from the beginning of 2008 to the end of 2010 were recorded at 11 sampling sites, which were examined in detail in this study to demonstrate the seasonal and diurnal oscillations of mercury levels. These sites included Mississippi (MS12), Oklahoma (OK99), Utah (UT96 and UT97), Ohio (OH02), Maryland (MD08), New York (NY95, NY20), New Hampshire (NH06), Vermont (VT99) and Nova Scotia (NS01) (Fig. 1). Except NY95 and UT97, all the sampling sites were rural sites with no significant emission sources within their $10 \mathrm{~km}$ radius. Detailed sites descriptions and local emission strengths calculated from 2005 National Emission Inventory are list in Table 1.

\subsection{Measurements and data}

Speciated mercury was measured in this network by a suite of automated Tekran mercury instrumentation. GEM was measured via a cold vapor atomic florescence (CVAF) spectrometer (Model 2537A or B) in a sequential dual channel mode with $5 \mathrm{~min}$. time resolution and a detection limit of $\sim 5-$ $10 \mathrm{ppqv}\left(1 \mathrm{ng} \mathrm{m}^{-3}=112 \mathrm{ppqv}\right)$. GOM was measured with a speciation unit (Model 1130) consisting of a $\mathrm{KCl}$ coated 
Table 1. Site description and mercury emission from nearby facilities.

\begin{tabular}{lllllllll}
\hline Site ID & Site Name & Latitude & Longitude & Elevation & Type & $\begin{array}{l}\text { Emission sources } \\
\text { at } \leq 10 \mathrm{~km} \\
\left(\mathrm{MT} \mathrm{yr}^{-1}\right)^{*}\end{array}$ & $\begin{array}{l}\text { Emission sources } \\
\text { at } \leq 50 \mathrm{~km} \\
\left(\mathrm{MT} \mathrm{yr}^{-1}\right)^{*}\end{array}$ \\
& & & & & & $\begin{array}{l}\text { Emission sources } \\
\text { at } \leq 150 \mathrm{~km} \\
\left.(\mathrm{MT} \mathrm{yr})^{-1}\right)^{*}\end{array}$ \\
\hline MS12 & Grand Bay NERR & 30.4294 & -88.4277 & 2 & Rural & 0 & 0.073 & 0.176 \\
MD08 & Piney Reservoir & 39.7053 & -79.0122 & 769 & Rural & $9.099 \times 10^{-6}$ & 0.014 & 0.600 \\
OK99 & Stilwell & 35.7514 & -94.6717 & 304 & Rural & $2.668 \times 10^{-10}$ & 0.001 & 0.692 \\
UT96 & Antelope Island & 41.0467 & -112.0248 & 1283 & Rural & $4.094 \times 10^{-9}$ & 0.074 & 1.225 \\
UT97 & Salt Lake City & 40.7118 & -111.9609 & 1297 & Urban & $9.380 \times 10^{-5}$ & 0.122 & 1.179 \\
OH02 & Athens Super Site & 39.3078 & -82.1182 & 275 & Rural & $1.347 \times 10^{-3}$ & 0.002 & 7.545 \\
NY20 & Huntington Wildlife & 43.9731 & -74.2231 & 500 & Rural & 0 & 0 & 0.463 \\
NY95 & Rochester & 43.1463 & -77.5481 & 136 & Suburban & $7.167 \times 10^{-2}$ & 0.113 & 0.269 \\
NH06 & Thompson Farm & 43.1100 & -70.9500 & 23 & Rural & $1.148 \times 10^{-3}$ & 0.059 & 0.213 \\
VT99 & Underhill & 41.0467 & -112.0248 & 399 & Rural & 0 & 0.005 & 0.082 \\
N501 & Kejimkujik & 44.4328 & -65.2056 & 155 & Rural & NA & NA & NA \\
& National Park & & & & & & & \\
\hline
\end{tabular}

* Calculated from U S EPA's 2005 National Emission Inventory point sources (facilities) data (http://www.epa.gov/ttn/chief/net/2005inventory.html).

The emission unit MT yr stands for metric tons per year.

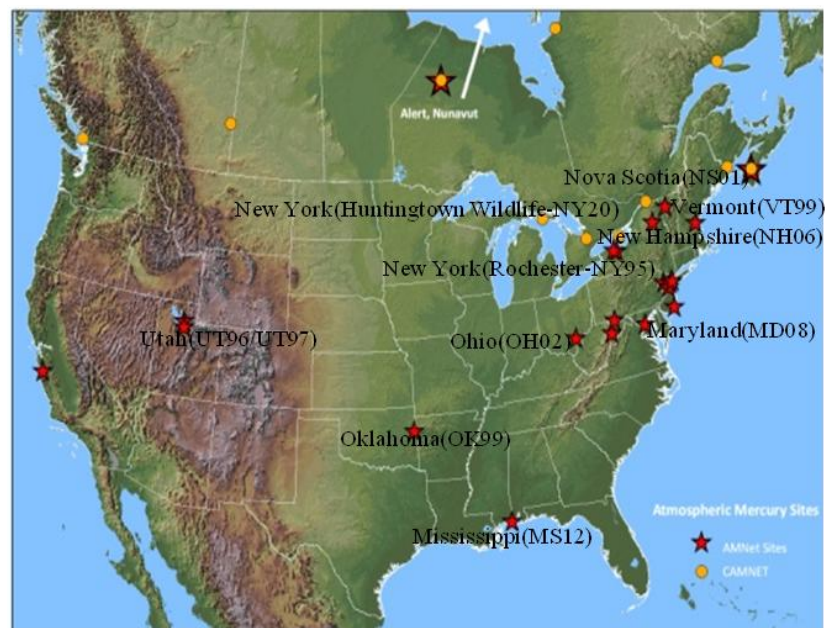

Fig. 1. Location of the 11 AMNet sites utilized in this study. This map is modified from AMNet site map available on: http://nadp. sws.uiuc.edu/amn/siteinfo.aspx.

denuder while PBM was trapped on a quartz frit (Model 1135). GOM and PBM were typically averaged over $2 \mathrm{~h}$ and then analyzed for $1 \mathrm{~h}$, and thus the dataset had $3 \mathrm{~h}$ time resolution. GEM data presented here are also $3 \mathrm{~h}$ time resolution, although the original data was typically $5 \mathrm{~min}$. time resolution. It is important to note that all instrumentation was operated in an identical manner according to standard operating procedures agreed to by the site operators. More details on instrument and operating procedures are presented on the AMNet website (http://nadp.sws.uiuc.edu/amn/docs.aspx).

The GEM mixing ratios were always above the detection limit of $\sim 0.05$ ppqv. The detection limit of GOM was estimated to be $0.05-0.1 \mathrm{ppqv}$, based on three times the standard deviation of average blank values determined at NH06 and
NY95 sites (Sigler et al.2009; Huang et al., 2010). The detection limit of PBM was estimated to be $0.1 \mathrm{ppqv}$ (Huang et al., 2010). No special treatment was applied to the GOM and PBM data that may have been less than the detection limit because, in our analysis, median values were utilized instead of mean values for site comparisons. Hourly diurnal profiles were achieved by utilizing the $2 \mathrm{~h}$ measurement data ( 1 data/2 hrs) to represent the starting and ending time points, as well as the middle time period.

\section{General characteristics}

\subsection{GEM}

The median mixing ratio of GEM was relatively uniform (Fig. 2), and varied within the range of $148-226 \mathrm{ppqv}$ (Table 2), which was similar to the current background GEM level in the Northern Hemisphere (Sprovieri et al.,2010). However, the UT97 sites exhibited a high median level (226 ppqv) and large standard deviation (95 ppqv), as well as frequent large spikes in its time series. From the 2005 National Emission Inventory (Table 1), it was clear that UT97 was heavily impacted by nearby anthropogenic emission sources (i.e., smelting activities, petroleum refining and landfills). Compared to the nearby UT96 site, UT97 exhibited a much higher GEM median level (about 50 ppqv higher, see Table 2) and more frequent large spikes. It is known that GEM has long lifetime and can be transported from long distant. However, the total emissions within $150 \mathrm{~km}$ radius areas of UT96 and UT97 were very similar, which cannot explain the large differences between their median mixing ratios. The local emissions of UT97 from its immediate area $(\leq 50 \mathrm{~km}$ emission), however, was much higher than UT96 site. It indicates that UT97 could capture more urban emissions, especially the emissions that originated from local point sources. 

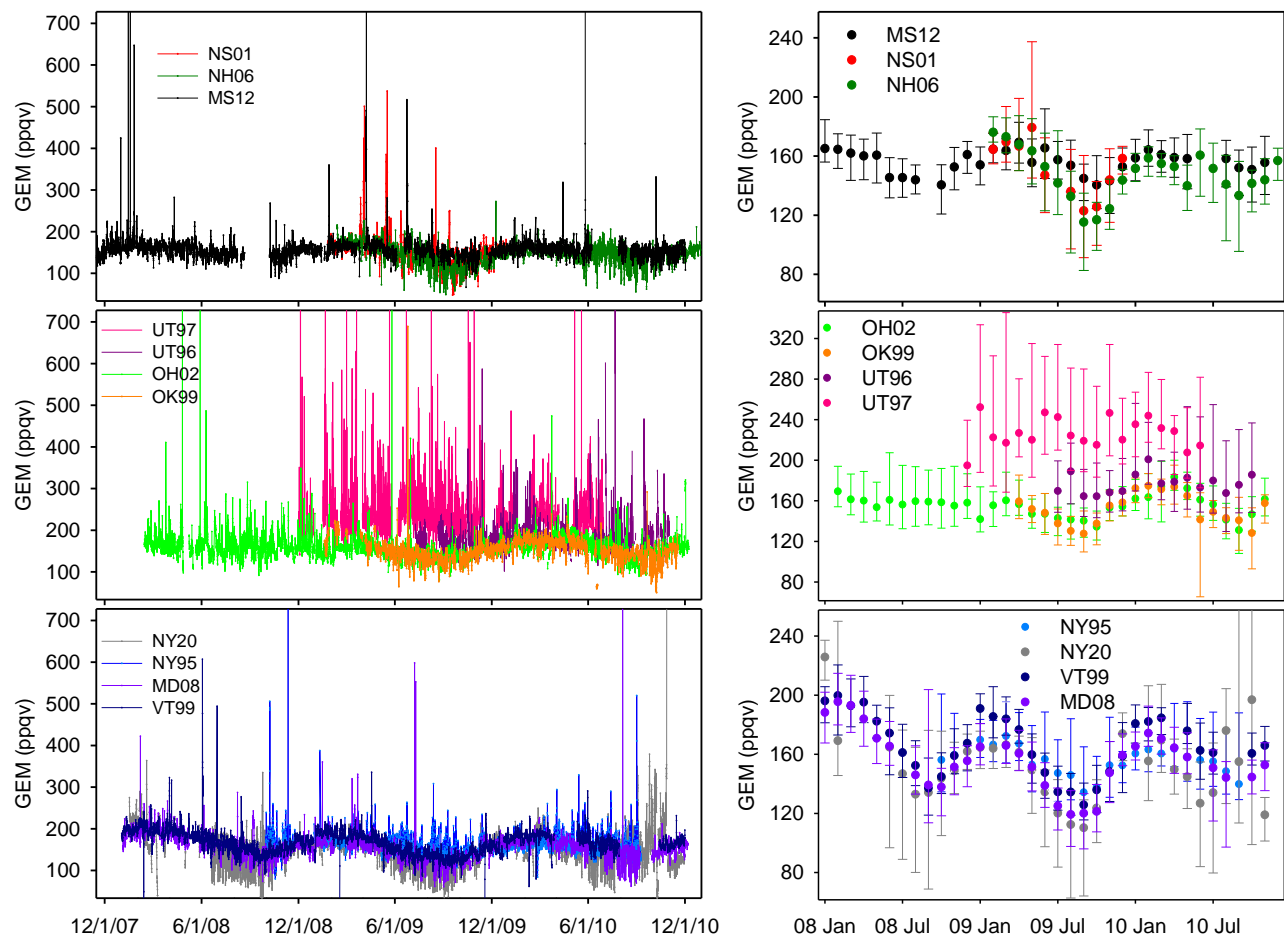

Fig. 2. Complete time series of GEM (left panel) and the monthly median mixing ratio at 11 sites. The upper error bars represent 90 percentile while the lower error bars represent 10 percentile values (right panel).

The UT96 site showed slightly higher median GEM levels than other rural sites, however, with a high standard deviation similar to UT97. This suggested that local emissions or point sources were very likely to be the dominant factors determining GEM mixing ratios in this region. Due to the elevations of these two sites, UT97 and UT96 could also capture long-distance transported mercury, which may include mining and/or Asian emissions (Jaffe et al., 2005; Strode et al., 2008).

The Ohio River Valley has a large number of coal-fired power plants; mercury compounds emitted by the facilities within $150 \mathrm{~km}$ radius of $\mathrm{OH} 02$ site were estimated to be more than 7.5 metric $\mathrm{yr}^{-1}$ according to the 2005 National Emission Inventory (Table 1). However, the median mixing ratio of GEM at the $\mathrm{OHO2}$ site was similar to the overall average for all sites. A feature of $\mathrm{OH} 02$ was that it demonstrated an exceptional high standard derivation of about 56 times that of other rural sites (Table 2). Although it had fewer large spikes than at UT97 (Fig. 2), OH02 probably intercepted downwind air masses from nearby point sources (such as coal-fired power plants, clay production and organic chemical industry emissions) frequently.

Coastal sites NS01 and NH06 showed especially low GEM values (as low as $\sim 50$ ppqv) in late summer to early fall. The lower GEM values may not be directly related to anthropogenic emissions because the local emissions (within $50 \mathrm{~km}$ radius) of NH06 were $0.059 \mathrm{MT}$ yr, signifi- cantly higher than other rural sites, such as MD08, OK99, OH02 and VT99 (Table 1). Instead, it may be caused by the influence of halogens converting GEM to GOM or PBM in coastal areas. Previous research has demonstrated that halogen oxidation of GEM may has substantial influence on GEM abundance for coastal airsheds (Laurier et al., 2003). In-depth analysis of the NH06 data also suggested that halogen chemistry was a reason for the significantly lower GEM levels and steeper decreasing trend during the warm season (Mao et al., 2008). However, the coastal site MS12 did not show especially low values during the late summer-early fall period. This suggested that meteorological factors, especially wind direction and speed that advect mercury from surrounding industries to the MS12 sampling site could be an important factor for its GEM variation.

Although GEM at sites across the US appeared to mimic each other closely in average value and seasonal temporal changes, discernible differences in mixing ratios can be found in monthly median GEM values (Fig. 2). For the same month, the differences among median values were as large as 30 ppqv (exclude the exceptional high UT97 value). This could result from significantly diverse emission sources and removal mechanisms.

\subsection{GOM}

The GOM mixing ratio is typically higher in urban or industrial areas, whereas it is lower in rural areas because it 
Table 2. The seasonal and total medians of GEM at 11 AMNet sites.

\begin{tabular}{|c|c|c|c|c|c|c|c|c|c|c|c|}
\hline & MS12 & MD08 & OK99 & UT96 & UT97 & $\mathrm{OH} 02$ & NY20 & NY95 & NH06 & VT99 & NS01 \\
\hline Winter 07 & 163 & 192 & & & & & 219 & & & 197 & \\
\hline Winter 08 & 160 & 162 & & & 212 & 153 & 163 & 169 & 150 & 183 & \\
\hline Winter 09 & 158 & 169 & 169 & 184 & 233 & 160 & 163 & 158 & & 177 & 158 \\
\hline Winter Ave & 161 & 174 & 169 & 184 & 223 & 157 & 182 & 163 & 150 & 186 & 158 \\
\hline Spring 08 & 161 & 185 & & & & 160 & 151 & & & 190 & \\
\hline Spring 09 & 163 & 161 & 157 & & 224 & 155 & 160 & 165 & 169 & 175 & 169 \\
\hline Spring 10 & 160 & 164 & 170 & 177 & 225 & 177 & 153 & 161 & 150 & 182 & \\
\hline Spring Ave & 161 & 170 & 164 & 177 & 225 & 164 & 155 & 163 & 160 & 182 & 169 \\
\hline Summer 08 & 145 & 155 & & & & 159 & 144 & & & 160 & \\
\hline Summer 09 & 158 & 127 & 138 & 176 & 237 & 144 & 122 & 149 & 141 & 138 & 142 \\
\hline Summer 10 & & 147 & 144 & 174 & 214 & 154 & 139 & 152 & 151 & 162 & \\
\hline Summer Ave & 151 & 143 & 141 & 175 & 226 & 152 & 135 & 151 & 146 & 153 & 142 \\
\hline Fall 08 & 147 & 142 & & & & 157 & 144 & 157 & & 148 & \\
\hline Fall 09 & 143 & 127 & 141 & 166 & 221 & 142 & 119 & 138 & 119 & 136 & 131 \\
\hline Fall 10 & 153 & 147 & 142 & 180 & & 147 & 135 & & 142 & 164 & \\
\hline Fall Ave & 148 & 139 & 142 & 173 & 221 & 149 & 132 & 147 & 130 & 149 & 131 \\
\hline Total Median & $157 \pm 25$ & $156 \pm 28$ & $153 \pm 25$ & $176 \pm 95$ & $226 \pm 95$ & $155 \pm 173$ & $148 \pm 49$ & $158 \pm 36$ & $149 \pm 23$ & $167 \pm 27$ & $156 \pm 34$ \\
\hline
\end{tabular}

* Total Median: median \pm standard deviation.
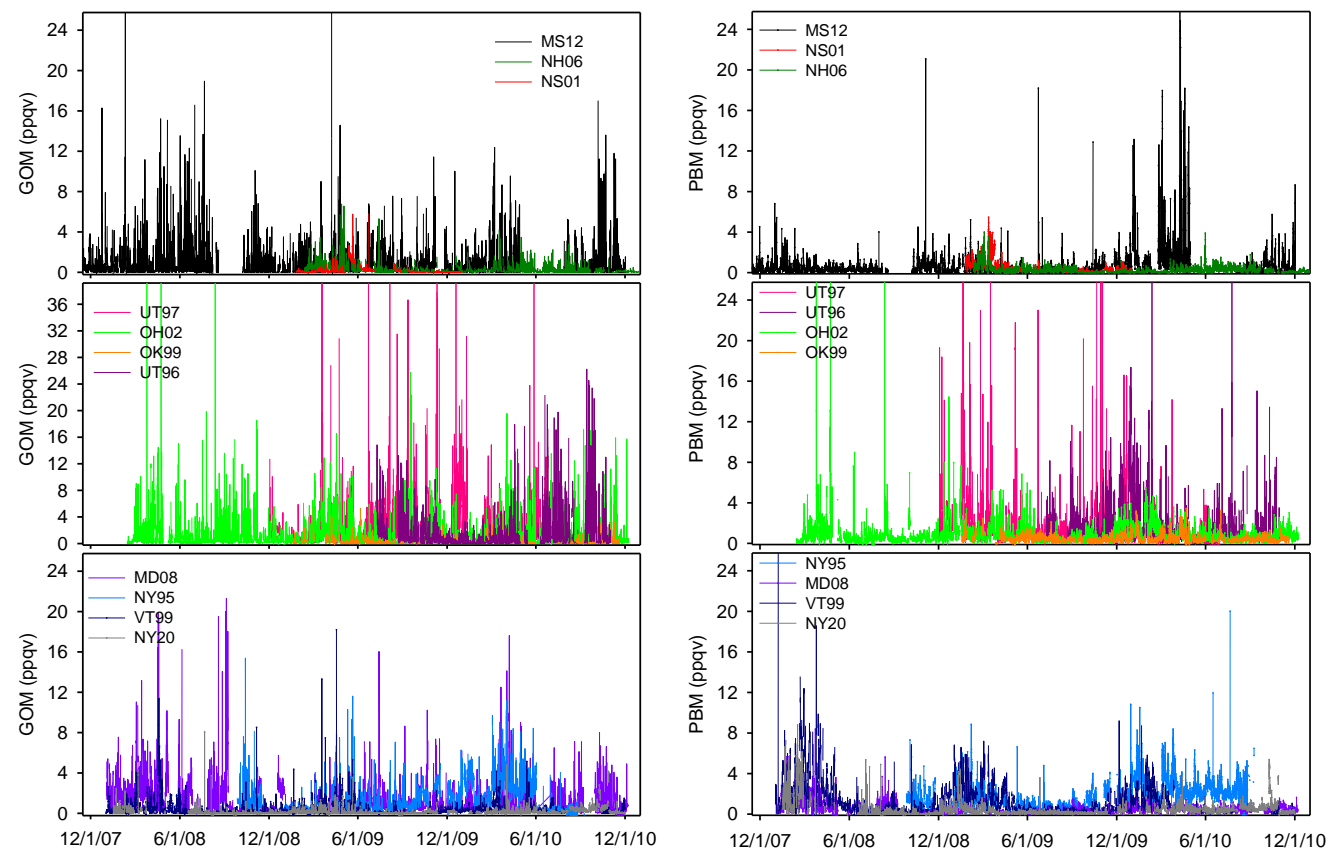

Fig. 3. Complete time series of GOM (left panel) and PBM (right panel).

is influenced primarily by local and regional sources due to its short atmospheric resident time. Valente et al. (2007) summarized previous global measurements and reported that the mean concentrations of GOM in remote or rural areas was $0.003-0.163 \mathrm{ng} \mathrm{m}^{3}(0.3-18.3 \mathrm{ppqv})$ with mean value of $0.018 \mathrm{ng} \mathrm{m}^{3}$ (2.0 ppqv). By comparison, in urban areas or near-point source sites it ranged from $0.0061-0.121 \mathrm{ng} \mathrm{m}^{3}$ (0.7-13.5 ppqv) with mean value of $0.052 \mathrm{ng} \mathrm{m}^{3}$ (5.8 ppqv). Our analysis of the AMNet dataset, including both rural and urban sites, showed that median GOM values ranged from
0.05 to 1.4 ppqv (Fig. 3), generally lower than previous measurements. It was also lower when compared with the measurements in the Mediterranean as well as Northern Europe (MOE and MAMCS campaigns) (Pirrone et al., 2001, 2003; Sprovieri et al., 2003; Wangberg et al., 2001), but consistent with a few rural sites measurements in the US, such as Chesapeake Bay, Maryland (6-13 $\left.\mathrm{pg} \mathrm{m}^{-3}\right)(0.7-1.5 \mathrm{ppqv})$ (Laurier and Mason, 2007) and Pompano Beach, Florida (1.6-4.9 $\left.\mathrm{pg} \mathrm{m}^{-3}\right)(0.2-0.5 \mathrm{ppqv})$ (Malcom et al., 2003). An apparent characteristic of GOM was its great diversity across 
the US (Fig. 3, Table 3). For coastal sites NH06 and NS01, they showed very low median GOM $(0.1 \mathrm{ppqv}$ and 0.05 ppqv) compared with MS12 (0.2 ppqv) even though emission sources within $10 \mathrm{~km}$ and $50 \mathrm{~km}$ radii of NH06 were comparable to MS12. Variation in wind direction may change the mercury transport pattern; however, GOM is lost quickly from an air mass via dry deposition and its mixing ratio diluted during transport (Valente et al., 2003). The nearby emission sources, if not immediate, may not have significant influences on the GOM levels measured at the monitoring sites.

For inland sites UT97 and UT96, they demonstrated relatively high GOM median levels (1.38 ppqv and $0.49 \mathrm{ppqv}$, respectively), as well as frequent large spikes in their time series (see Fig. 3). The 2005 NEI facilities emissions data showed that UT96 and UT97 had higher mercury emissions within their $150 \mathrm{~km}$ radius compared with other AMNet sites, except $\mathrm{OH} 02$ (Table 1). Heavy industrial facility emissions could contribute to these characteristics. However, photochemically driven oxidation of GEM was likely responsible for elevated GOM levels in this area. Previous measurements at the Great Salt Lake area reported high mixing ratios of atmospheric reactive chlorine and bromine that could enhance the atmospheric oxidation capacity and thus influence the atmospheric mercury budget in the area (Stutz et al., 2002).

At NY95, the median GOM mixing ratio was 0.7 ppqv, the second highest among all the sampling sites. Considering that NY95 has the highest mercury emission sources in its immediate surrounding area $(<10 \mathrm{~km})$ (Table 1$)$, this feature probably resulted from the enhanced local emissions, such as paper production, photographic equipment and nearby coalfired power plant (from 2005 NEI facilities data). The median GOM mixing ratio at the $\mathrm{OH} 02$ site was $0.5 \mathrm{ppqv}$, only slightly higher than other rural sites; however, the GOM variation (Std. Dev. $=5.2$ ppqv) was the largest of all AMNet sites. This implied that the locally heavy coal combustion emissions had great influence on the GOM fluctuations rather than on the median mixing ratio at $\mathrm{OH} 02$ site. In-depth research at $\mathrm{OH} 02$ site reported intensive episodic GOM events (GOM> 3.9 ppqv), besides low background concentrations (Yatavelli et al, 2006). GOM correlated well with $\mathrm{SO}_{2}$ (correlation coefficient $r=0.61)$, and even better $(r=0.80)$ during some episodic events (Yatavelli et al, 2006), which supported the hypothesis that local and regional coal-fired power plants may be the primary factor influencing $\mathrm{GOM}$ at $\mathrm{OH} 02$. In contrast, the mid-US site in Oklahoma exhibited very low GOM values, probably due to the limited source of direct industrial emissions and lack of halogen oxidants (Table 1).

\subsection{PBM}

PBM mixing ratios were very different among the AMnet sites (Fig. 3), ranging from 0.18 ppqv to 1.5 ppqv. An interesting and surprising feature of PBM was that its median mixing ratios at all coastal sites were statistically lower
( $p \leq 0.001)$ than at inland sites, with 0.26 ppqv difference in medians values between coastal and inland sites. In the coastal environment, sea salt aerosols can take-up GOM and produce considerable amounts of PBM. Halogen compounds in the coastal area can also convert GEM to GOM, which also help to increase the mixing ratios of PBM. However, the uptake of GEM and GOM by sea salt aerosols was not apparent from the monitoring data, even for the MS12 site which was only $5 \mathrm{~km}$ inland from the Gulf of Mexico. It was not clear if anthropogenic emissions were directly important to the significantly lower PBM levels at coastal site; however, the local emissions of $\mathrm{NH} 06$ and MS12 (within $50 \mathrm{~km}$ radii) were not significantly lower than most inland sites. This feature of the data may be an artifact due to the inefficiency of the PBM instrument to measure large aerosols because the elutriator inlet design of the Tekan 1135 removes aerosols $>2.5 \mu \mathrm{m}$, which could be problematic in the marine environment with sea salt in the $2-10 \mu \mathrm{m}$ range. Talbot et al. (2011) replaced the elutriator with one that contained no impaction plate to facilitate collection of coarse aerosols on the quartz frit in the Tekran 1135 during a campaign on Appledore Island in the Gulf of Maine and at the coastal site NH06. They found that the Tekan instrument underestimated PBM by as much as a factor of 3 for certain time periods. Thus, it was very likely that PBM in the airshed of AMNet coastal sites were much higher than the monitoring data suggested. Indeed, Talbot et al. (2011) and Feddersen et al. (2012) found similar levels of PBM at NH06 and Appledore Island using bulk aerosol collection on Teflon filters.

At sites in the Northeast (VT09, NH06, NY20 and NS01) they showed conspicuous seasonality with the highest mixing ratios appearing in winter and spring. High PBM in winter may be caused by colder temperatures and biomass burning in that period (i.e., residential wood burning). Wood smoke with increased potassium and organic carbon concentrations were identified in winter near NY20 sampling site (Choi et al., 2008). Forest fires can also attribute to elevated PBM mixing ratio. To illustrate this point, Fig. 4 depicts speciated mercury levels in the northeastern US when a series of forest fire events occurred in Quebec, Canada in late spring and early summer of 2010. The fire was started by lightning on the morning of May 25 and the fire plume was captured by the VT09, NH06, and NY20 sampling sites on the following days. The forest fire induced elevated speciated mercury levels, especially for PBM. This fire event was also studied by Wang et al. (2010) with a focus on mercury mixing ratios and carbonaceous particles around the NY20 site. Besides the obvious enhancement of PBM, high correlation between PBM and Delta-C (Delta-C $=$ Ultraviolet Black

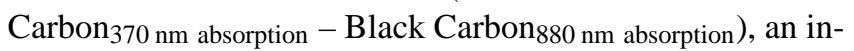
dicator of wood combustion particles, was found during the fire event.

In general, the observed speciated mercury mixing ratios were linearly correlated with anthropogenic emissions within a $50 \mathrm{~km}$ radius of the sampling sites (Fig. 5), with 
Table 3. The seasonal and total medians of GOM at 11 AMNet sites.

\begin{tabular}{|c|c|c|c|c|c|c|c|c|c|c|c|}
\hline & MS12 & MD08 & OK99 & UT96 & UT97 & $\mathrm{OH} 02$ & NY20 & NY95 & NH06 & VT99 & NS01 \\
\hline Winter 07 & 0.17 & 1.54 & & & & & 0.27 & & & 0.29 & \\
\hline Winter 08 & 0.11 & 0.44 & & & 0.83 & 0.34 & 0.08 & 0.28 & 0.09 & 0.12 & \\
\hline Winter 09 & 0.19 & 0.61 & 0.07 & 0.16 & 3.06 & 0.52 & 0.09 & 1.64 & & 0.26 & 0.02 \\
\hline Winter Ave & 0.16 & 0.86 & 0.07 & 0.16 & 1.94 & 0.43 & 0.15 & 0.96 & 0.09 & 0.23 & 0.02 \\
\hline Spring 08 & 0.25 & 1.89 & & & & 0.98 & 0.17 & & & 0.43 & \\
\hline Spring 09 & 0.18 & 0.81 & 0.21 & & 0.89 & 0.88 & 0.08 & 0.50 & 0.41 & 0.25 & 0.12 \\
\hline Spring 10 & 0.27 & 0.55 & 0.10 & 0.36 & 1.23 & 0.80 & 0.10 & 2.89 & 0.13 & 0.61 & \\
\hline Spring Ave & 0.23 & 1.08 & 0.16 & 0.36 & 1.06 & 0.89 & 0.12 & 1.69 & 0.27 & 0.43 & 0.12 \\
\hline Summer 08 & 0.33 & 1.16 & & & & 0.44 & & & & 0.05 & \\
\hline Summer 09 & 0.36 & 0.64 & 0.10 & 1.47 & 1.81 & 0.20 & & 0.38 & 0.10 & & 0.26 \\
\hline Summer 10 & & 0.36 & 0.06 & 1.05 & 2.49 & 0.17 & 0.10 & 0.34 & 0.05 & 0.09 & \\
\hline Summer Ave & 0.35 & 0.72 & 0.08 & 1.26 & 2.15 & 0.27 & 0.10 & 0.36 & 0.08 & 0.07 & 0.26 \\
\hline Fall 08 & 0.19 & 0.34 & & & & 0.66 & & 0.82 & & 0.04 & \\
\hline Fall 09 & 0.30 & 0.53 & 0.07 & 0.56 & 1.22 & 0.57 & & 1.39 & 0.11 & & 0.02 \\
\hline Fall 10 & 0.24 & 0.47 & 0.10 & 0.96 & & 0.50 & 0.28 & & 0.05 & 0.04 & \\
\hline Fall Ave & 0.24 & 0.44 & 0.08 & 0.76 & 1.22 & 0.58 & 0.28 & 1.11 & 0.08 & 0.04 & 0.02 \\
\hline Total Median & $0.22 \pm 1.58$ & $0.63 \pm 1.70$ & $0.10 \pm 0.49$ & $0.49 \pm 2.58$ & $1.38 \pm 3.80$ & $0.47 \pm 5.17$ & $0.06 \pm 0.33$ & $0.74 \pm 1.58$ & $0.10 \pm 0.45$ & $0.13 \pm 0.73$ & $0.05 \pm 0.45$ \\
\hline
\end{tabular}

* Total Median: median \pm standard deviation.

correlation coefficients $\left(R^{2}\right)$ of 0.36 for GEM, 0.46 for GOM and 0.33 for PBM. This indicates that ambient speciated mercury tends to increase when anthropogenic emissions increase. The reason why the correlation between GOM and emissions was better was probably because GOM has short lifetime and stronger dependence on local emissions, while GEM can be influenced by long-range transport and PBM could be limited by aerosol abundance. We should also notice that the 2005 emission inventory is not up to date and may not reflect the complete anthropogenic emission sources, which maybe an important reason for the low coefficients between speciated mercury levels and emissions.

Natural emissions can also cause temporal and spatial variations in speciated mercury levels. The 11 AMNet sites were located in different areas with distinct land surface conditions. The Utah area is dominated by desert and dry shrub, and Oklahoma is dominated by temperate deciduous forest and grassland. The rest of the sampling sites are dominated by deciduous and mixed forests. Vegetation emissions have been found to be related to the ambient mercury concentration (Graydon et al., 2006), and the soil emission influenced by solar radiation and soil mercury content (Sigler and Lee, 2006). Thus the vegetation and soil emissions were likely different across these AMNet sites with large gradients in ambient and soil mercury contents and solar radiation. However, natural emissions of mercury typically have low flux values compared to anthropogenic emissions, even though the natural emissions were estimated to release a large amount of mercury and comparable to anthropogenic emissions (Selin, 2009). It was reported that the averaged emission rate in the city of Basel, Switzerland was $6.4 \pm 0.9 \mathrm{ng} \mathrm{m}^{-2} \mathrm{~h}^{-1}$, while the averaged emission rate at a subalpine grassland was only $0.2 \pm 0.3 \mathrm{ng} \mathrm{m}^{-2} \mathrm{~h}^{-1}$ (Obrist et al., 2006). Measurements over a soil with natural background mercury concentration reported that the mean deposition flux was only 0.6 to $2.2 \mathrm{ng} \mathrm{m}^{-2} \mathrm{~h}^{-1}$ under visible light and photosynthetically active radiation (Xin et al., 2007). Thus, in most cases natural mercury emissions may exert a small influence on a regional area.

\section{Seasonal trends}

On average, GEM was highest in spring at NS01, MS12, NH06, OH02, but peaked in winter at MD08, NY20, VT99 and UT96 (Table 2). For most AMNet sites, the lowest values appeared in fall. High GEM in winter or spring was possibly associated with coal and natural gas combustion and increased wood burning for heating during the cold season. In addition, weakened sinks due to the lower atmospheric oxidative capacity and poor vertical mixing caused by a decreased boundary layer height may have led to higher GEM values. Low GEM mixing ratios in warmer seasons were probably due to the increased temperature and solar radiation that favor GEM oxidation. GEM can be transformed to GOM and be subsequently removed from the atmosphere.

Large variations exist in the seasonal median GEM levels in different years and at different sampling sites (see Table 2). The wintertime GEM median mixing ratios in 2007 were higher than in 2008 (3-56 ppqv higher, Table 2) and 2009 (5-56 ppqv higher, Table 2), based on the available data from MS12, MD08, NY20 and VT99 sites. The wintertime and springtime GEM levels at VT99 were especially greater than at other rural sites, which was probably related to biomass burning (wood burning) in that area. The monitoring sites MD08, UT97, NY20 and VT99 varied by more than 20 ppqv in summertime median values. The MD08, NY20, NH06 and VT99 sites exhibited large inter-annual differences in the fall seasons. These were probably the consequence of different annual meteorological conditions.

Higher GOM levels were found in spring at MD08, NH06, NY95, OH02, OK99 and VT99. At other sites, such as NS01, 

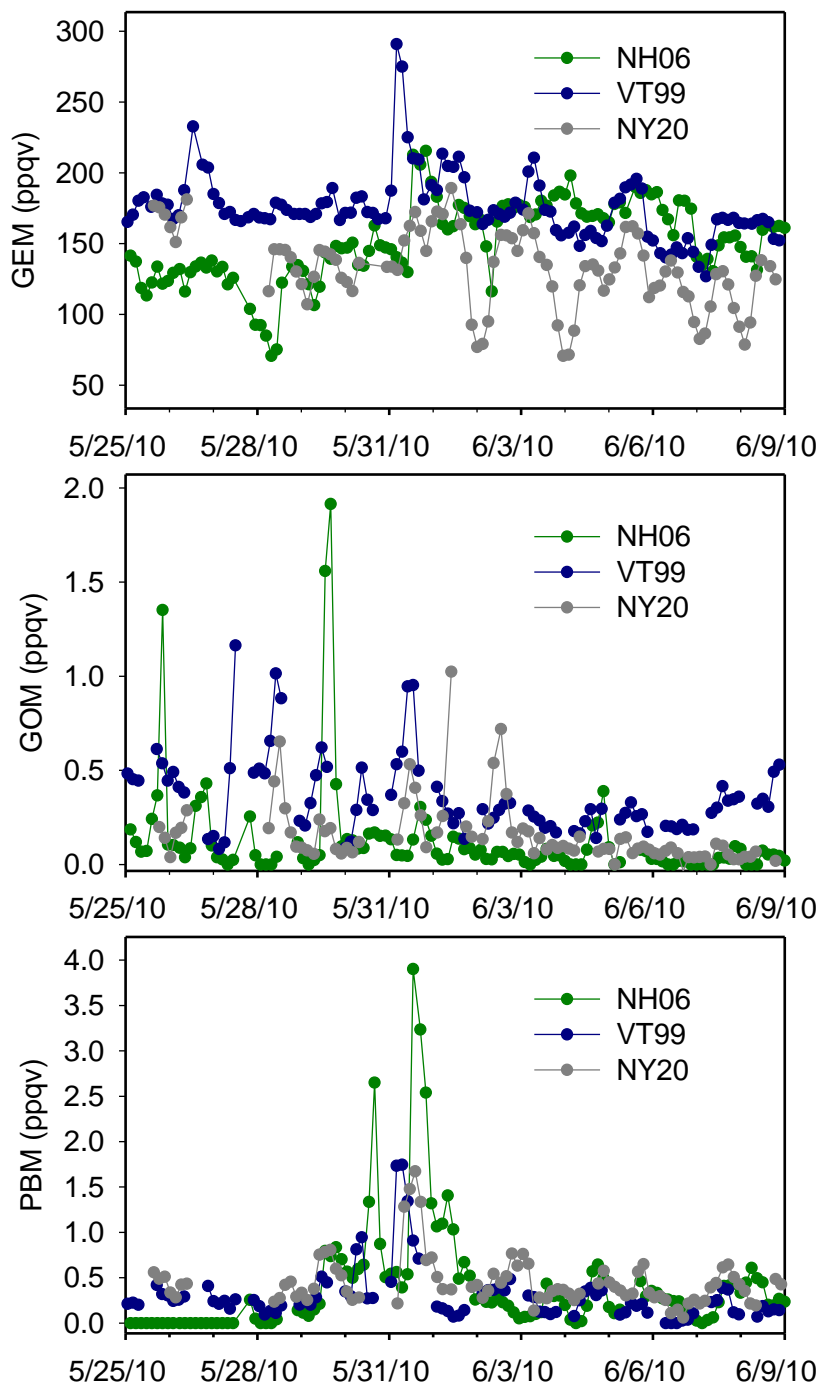

Fig. 4. Speciated mercury mixing ratios during the 2010 spring Quebec fire event.

MS12, UT96 and UT97, GOM peaked in summer (Table 3). GOM can be emitted directly from industries, such as coalfired power plants and waste incinerators, as well as generated from photochemistry reactions of GEM and various oxidants. Higher GOM mixing ratios in spring and summer may be due to the increased length of the growing season at this time, where there is longer exposure time to solar radiation and increasing temperatures (Lai et al., 2012).

PBM was highest in winter at most sites (Table 4). This may result in some locations from wood burning emissions from residential heating. In general, colder temperatures favor partitioning to the aerosol phase (Seinfeld and Pandis, 2006) in addition to decreased removal from the atmosphere (Mao et al., 2011; Amos et al., 2012).

\section{Diurnal variation}

\subsection{GEM}

The springtime GEM diurnal variation was modest. The averaged variation amplitude ranged from $5 \mathrm{ppqv}$ to $16 \mathrm{ppqv}$ in the three spring seasons (Figs. 6, S1). NY95 and UT97 showed the highest variation amplitudes (11 and 16 ppqv respectively) with similar diurnal patterns that peaked at midnight and dipped around 15:00 local standard time. NY20 exhibited the third highest amplitude variation with the diurnal maxima at 11:00-12:00 LST and minima at 05:00 LST.

GEM diurnal variation was most prominent in summer, even though the seasonal median GEM mixing ratios at most monitoring sites were lower than in spring and winter. The variation amplitudes ranged from $8 \mathrm{ppqv}$ (at MS12) to 55 ppqv (at UT97) in summer 2009 (Fig. 6). Seven rural sites, including MD08, OH02, NH06, NY20, VT99, NS01 and OK99, displayed a similar diurnal pattern in that the lowest GEM levels appeared in the early morning and then increased after sunrise and reached its maxima level at noon or in early afternoon. At MD08, daily minima were found at 05:00 or 06:00 LST, and maxima at 11:00-12:00 LST. The OK99 site appeared to have a similar diurnal pattern to MD08, and exhibited significantly lower summer GEM levels than in spring ( $>20$ ppqv difference). NY20 showed the lowest mixing ratios at 04:00-05:00 LST in all summer seasons, whose values were even lower than 100 ppqv. The highest GEM levels were found at 14:00 LST and the daily difference reached 65 ppqv in 2008, corresponding to about $50 \%$ when referred to the summer average value (Fig. S2). Studies using the CAMNet TGM data found that seven of its rural sites (including the NS01 site) displaced diurnal cycles that had minimum concentrations just before sunrise and maximum concentrations around solar noon (Kellerhals et al., 2003), which is similar with the AMNet results. The nighttime depletion of TGM underneath the nocturnal inversion layer was considered as the main cause for this pattern (Kellerhals et al., 2003). Mao et al. (2008) and Talbot et al. (2005) conducted detailed analyses on trace gases at Thompson Farm (NH06), and proposed that the nighttime low levels may result from the presence of the nocturnal inversion layer and chemical and physical processes acting underneath it. Box model simulations by Kim et al. (2010) further demonstrated that the dissolution of GEM by dew was likely responsible for the low levels of GEM before sunrise. The dissolved GEM then re-volatilized after sunrise, increasing the GEM mixing ratios in the morning. The maximum GEM mixing ratio at noon or early afternoon was likely due to the morning re-volatilization and downward mixing of remnant boundary layer air (Mao and Talbot, 2011; Selin et al., 2007; Weiss-Penzias et al., 2009). GEM levels decreased when solar radiation reached its maximum, which was probably a consequence of dilution 

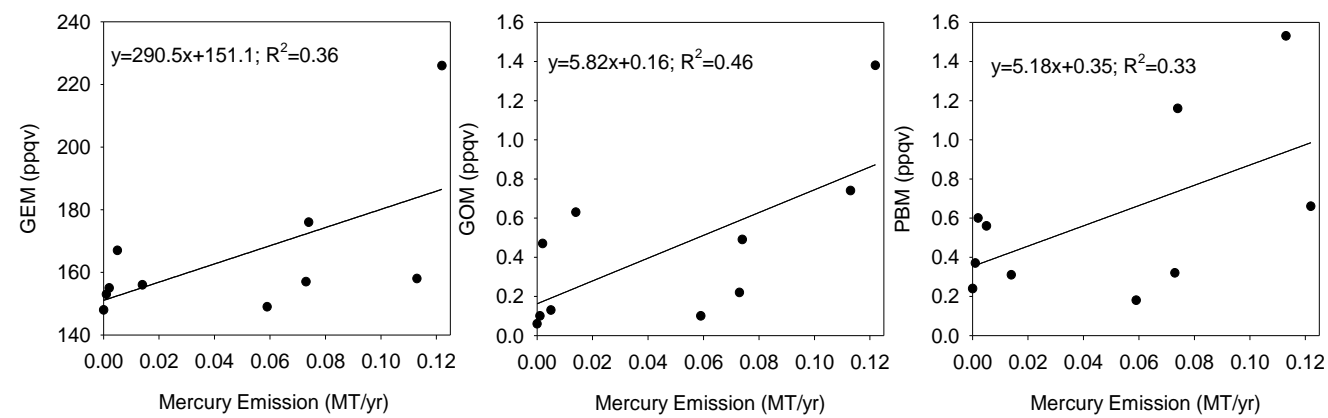

Fig. 5. Median values of GEM (left panel), GOM (middle panel) and PBM (right panel) versus the 2005 NEI anthropogenic mercury emissions within $50 \mathrm{~km}$ radius of the sampling sites. Refer to Table 1,2,3 and 4 for precise values.
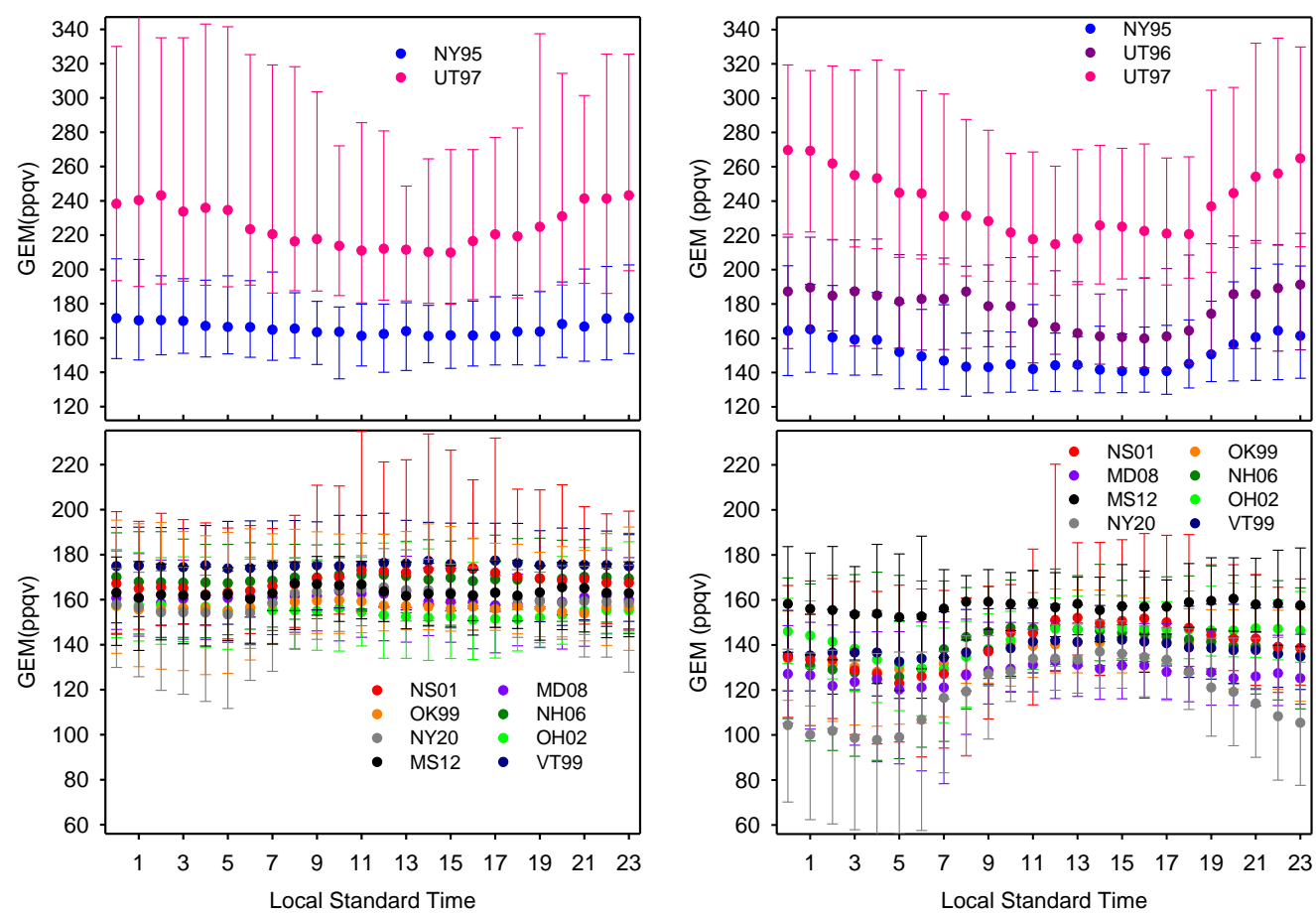

Fig. 6. GEM diurnal variation in 2009 spring (left panel) and 2009 summer (right panel). The upper error bars represent 90 percentile while the lower error bars represent 10 percentile values.

from increasing boundary layer height and GEM oxidation by photochemical processes to GOM and/or PBM.

Four AMNet sites exhibited different patterns of GEM diurnal variation in summer. The daily dips at MS12 were relatively noticeable at 04:00-06:00 LST, whereas the daily peaks were difficult to define. Albeit the fluctuation in 2008 and 2009 were not significant, we observed a weak decrease in GEM around 09:00 LST, much earlier than at the rural sites. The meteorology in this area may be responsible for this difference; however, the influence of halogen chemistry may also be an important factor for the early decline of GEM. The sites UT96, UT97 and NY95 showed a distinct pattern with the lowest mixing ratios appearing in the afternoon and highest mixing ratios at night. Considering that all these sites are located near lakes, it was possible that the land/lake breeze and special boundary layer structure in those areas caused the unusual variation pattern. Low mercury content air was found at NY95 in summer 2008 when the wind was advected from the northeast over Lake Ontario (Huang et al., 2010). A similar diurnal pattern was found at Reifel Island (CAMNet) site, which was caused by the land breeze advection of urban air to this site at night and lake breeze advection of clean air during daytime (Kellerhals et al., 2003). Other prossesses that were potentially related to this diurnal pattern was the strong daytime vertical mixing that brought clean air aloft to the ground and then diluted the surface emissions during daytime. The sites UT97, UT96 and NY95 were heavily polluted sites (refer to the emissions $\leq 50 \mathrm{~km}$ at Table 1 ), 

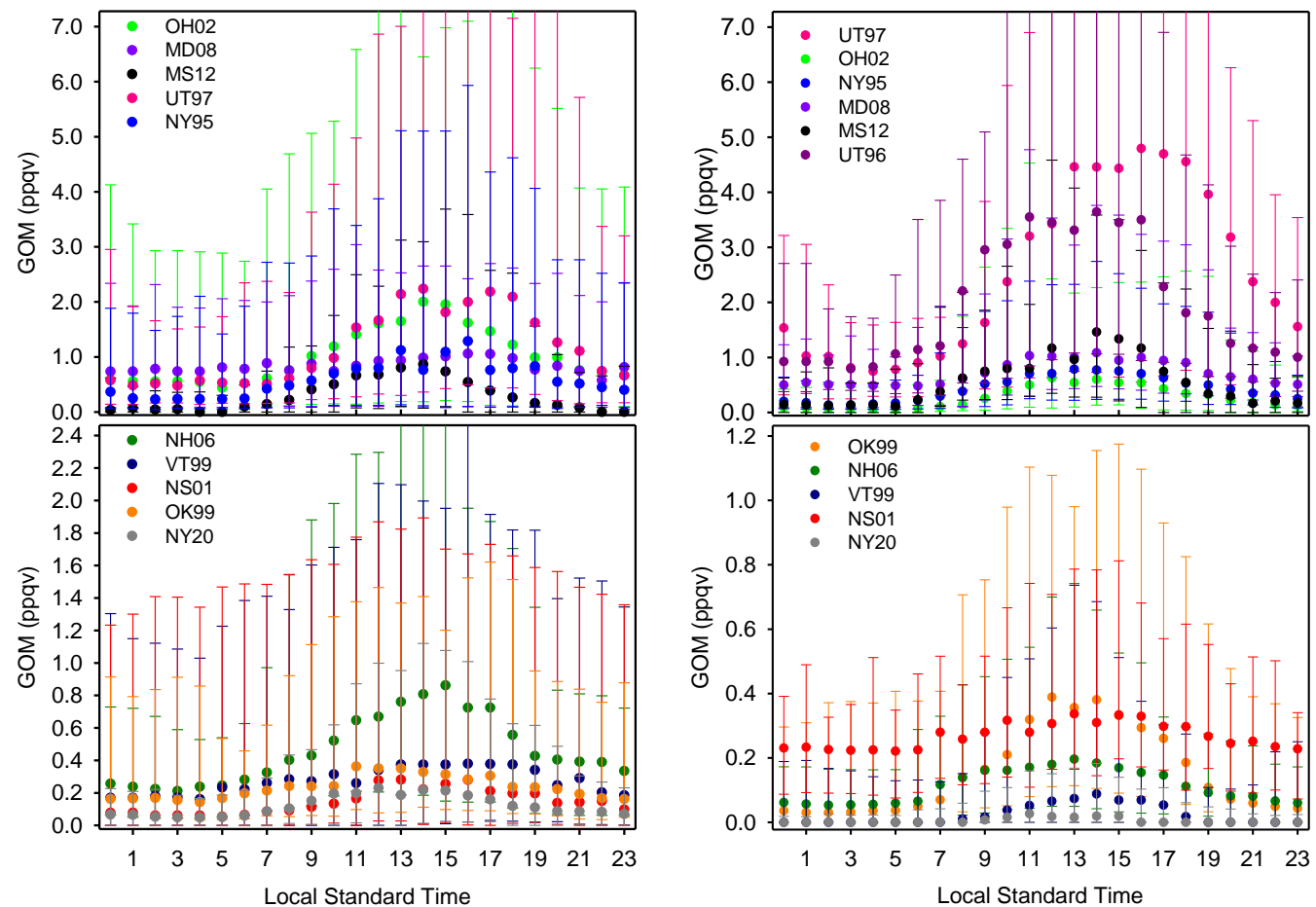

Fig. 7. GOM diurnal variation in 2009 spring (left panel) and 2009 summer (right panel). The upper error bars represent 90 percentile while the lower error bars represent 10 percentile values.
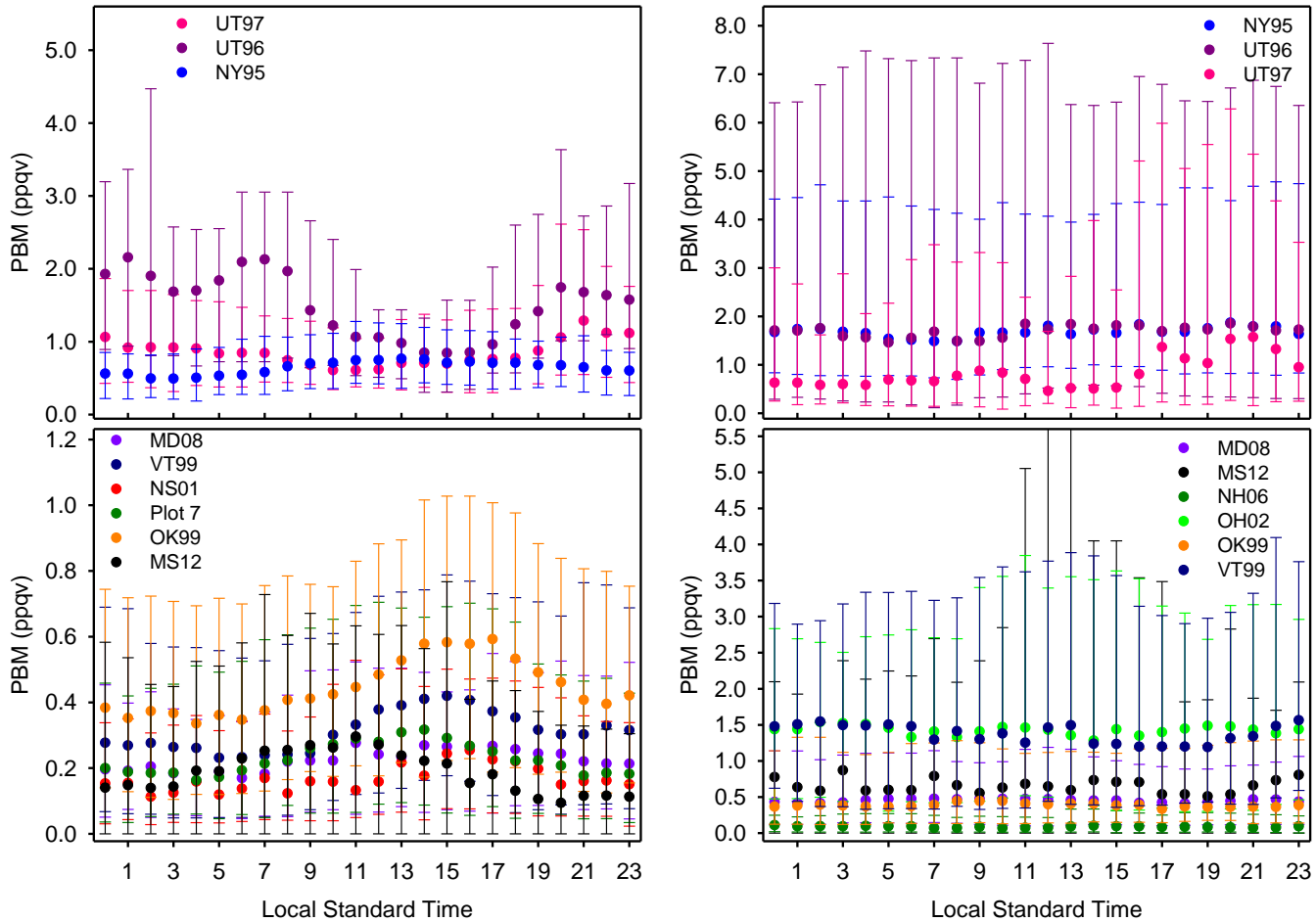

Fig. 8. PBM diurnal variation in 2009 summer (left panel) and winter (right panel). The upper error bars represent 90 percentile while the lower error bars represent 10 percentile values. 
Table 4. The seasonal and total medians of PBM at 11 AMNet sites.

\begin{tabular}{|c|c|c|c|c|c|c|c|c|c|c|c|}
\hline & MS12 & MD08 & OK99 & UT96 & UT97 & $\mathrm{OH} 02$ & NY20 & NY95 & NH06 & VT99 & NS01 \\
\hline Winter 07 & 0.32 & 1.05 & & & & & 2.00 & & & 2.42 & \\
\hline Winter 08 & 0.34 & 0.33 & & & 1.62 & 0.81 & 0.42 & 1.56 & 0.09 & 1.77 & \\
\hline Winter 09 & 0.67 & 0.49 & 0.39 & 1.71 & 0.81 & 1.44 & 0.35 & 1.68 & & 1.34 & 0.18 \\
\hline Winter Ave & 0.44 & 0.62 & 0.39 & 1.71 & 1.22 & 1.13 & 0.92 & 1.62 & 0.09 & 1.84 & 0.18 \\
\hline Spring 08 & 0.28 & 0.87 & & & & 0.86 & 0.80 & & & 1.52 & \\
\hline Spring 09 & 0.24 & 0.13 & 0.45 & & 0.56 & 0.84 & 0.14 & 1.00 & 0.27 & 1.01 & 0.53 \\
\hline Spring 10 & 1.18 & 0.43 & 0.36 & 0.71 & 0.19 & 0.72 & 0.46 & 2.30 & 0.19 & 0.65 & \\
\hline Spring Ave & 0.56 & 0.48 & 0.40 & 0.71 & 0.37 & 0.81 & 0.47 & 1.65 & 0.23 & 1.06 & 0.53 \\
\hline Summer 08 & 0.25 & 0.65 & & & & 0.45 & 0.09 & & & 0.43 & \\
\hline Summer 09 & 0.16 & 0.21 & 0.43 & 1.43 & 0.84 & 0.32 & 0.14 & 0.65 & 0.22 & 0.31 & 0.16 \\
\hline Summer 10 & & 0.38 & 0.34 & 1.13 & 0.12 & 0.45 & 0.46 & 2.23 & 0.33 & 0.21 & \\
\hline Summer Ave & 0.20 & 0.42 & 0.39 & 1.28 & 0.48 & 0.41 & 0.23 & 1.44 & 0.27 & 0.32 & 0.16 \\
\hline Fall 08 & 0.51 & 0.11 & & & & 0.45 & & 1.31 & & 0.38 & \\
\hline Fall 09 & 0.31 & 0.29 & 0.28 & 1.15 & 0.82 & 0.49 & 0.08 & 1.29 & 0.04 & 0.38 & 0.09 \\
\hline Fall 10 & 0.32 & 0.38 & 0.35 & 1.14 & & 0.66 & 0.42 & & 0.10 & 0.09 & \\
\hline Fall Ave & 0.38 & 0.26 & 0.31 & 1.15 & 0.82 & 0.53 & 0.25 & 1.30 & 0.07 & 0.29 & 0.09 \\
\hline Total Median & $0.32 \pm 1.29$ & $0.31 \pm 0.58$ & $0.37 \pm 0.36$ & $1.16 \pm 4.11$ & $0.66 \pm 6.98$ & $0.60 \pm 6.47$ & $0.24 \pm 0.76$ & $1.53 \pm 1.26$ & $0.18 \pm 0.36$ & $0.56 \pm 1.60$ & $0.27 \pm 0.66$ \\
\hline
\end{tabular}

* Total Median: median \pm standard deviation.

where GEM emissions maybe higher than other rural sites. When the local emission rate is higher than deposition rate, GEM can accumulate and reach higher levels at night in the nocturnal boundary layer. Nair et al. (2012) found similar GEM diurnal patterns at an urban site at Atlanta, Georgia, and suggested that vertical mixing was likely the cause. At UT97, the largest diurnal difference reached 55 ppqv; similar diurnal differences were found in the same area by Peterson and Gustin (2008), revealing the exceptionally large daily loss of GEM near the Great Salt Lake.

The fall diurnal variation pattern was similar to that in summer, but with smaller amplitude and lower mixing ratio (Fig. S3). The daily dip at NY20 was dampened, compared with extremely low summertime GEM mixing ratios around mid-night. The winter GEM oscillations were barely noticeable for almost all sites (Fig. S4). It is important to note that the GEM data for this analysis is $3 \mathrm{~h}$ resolution data. Mao and Talbot (2011) found larger diurnal variations, ranging from 20 ppqv to 40 ppqv, in summers and falls of 2004-2010 at NH06, by using higher resolution data (i.e., $5 \mathrm{~min}$ ).

\subsection{GOM}

Most AMNet sites showed a springtime diurnal pattern where the daily maxima appeared at 12:00-16:00 LST, and a much less noticeable minimum around 04:00-06:00 LST (Figs. 7, S5). The only exception was NY95 in 2010 which showed a different diurnal pattern that dipped at 10:00 and peaked at 18:00 local time. Regarding the difference in variation amplitude, we separated the sampling sites into two groups: (1) the first group included MS12, MD08, OH02, NY95, UT97 and UT96, whose daily oscillation amplitude was $>1$ ppqv in most spring seasons; and (2) the second group included OK99, NY20, NH06, VT99 and NS01, whose daily variation amplitude was $<0.6 \mathrm{ppqv}$ in most spring seasons. The largest GOM daily variation amplitude
(2-3 ppqv) was found at UT97, which could be related to the comparatively larger nearby anthropogenic emissions. However, UT97 exhibited large GEM daily variation (16 ppqv), and reduced mixing ratios at daytime while the GOM mixing ratios increased significantly. Considering the possibly of high halogen emissions in the Great Salt Lake area, photochemical oxidation of GEM was likely a dominant factor controlling GOM.

The summertime daily variation pattern at NY20 was very similar to that in springtime, whose maxima appeared at 12:00-15:00 and minima appeared at 02:00-05:00 LST (Fig. 7). Previous work at NY20 found a daily GOM maximum in the afternoon and minima before sunrise and significant correlations between GOM and ozone and temperature in summer (Choi et al., 2008). GOM shares similarity with ozone because it is also produced by photochemical reaction. This suggested that temperature and solar radiation may be significant for the diurnal variation of GOM. The variation amplitudes in summer were generally smaller than in spring, except for 2008 and 2009 at MS12, 2009 of MD08, OK99 and UT97. The first group showed amplitude variation $>0.5$ ppqv, while the second group was $<0.3$ ppqv. Thus the amplitude differences between these two groups were found to be consistent with the springtime distribution. The Utah sites showed significantly larger diurnal variation compared with springtime. The diurnal variation in 2009 summer at UT96 was more than $2.5 \mathrm{ppqv}$, while the variation at UT97 site was about 4 ppqv (Fig. 7). This feature was probably caused by the increased atmospheric oxidative capacity in summer due to the presence of halogen species and the enhanced temperature. The largest summer diurnal oscillation was found at UT96 in 2010 summer, demonstrating a 5.2 ppqv variant that was 5 -fold of the 2010 summer median level (Fig. S6).

The fall GOM daily variation pattern was very similar to the spring and summer patterns, whose minima 
appeared after mid-night and maxima in the afternoon (S Fig. 7). The diurnal variation amplitudes were also comparable with spring and summertime, although the amplitudes were slightly smaller at a few sites such as VT99 and NS01. The amplitude variation in fall 2009 was smaller than that in 2010 at most AMNet sites. In winter, the diurnal variation amplitude was dampened, and even became flat at MD08 and OK99 (S Fig. 8).

It is interesting to note that the minima in median mixing ratios at MS12 were especially lower than at other rural sites. The minima almost reached zero in all spring seasons as well as the summer and fall of 2010, which occurred more frequently compared to other sites. This phenomenon may be related to the high nighttime air humidity in the Mississippi area that favored the deposition of GOM into dew. Recent research at the NH06 location found out that GOM mixing ratios had a decreasing tendency when relative humidity increased, especially in the spring season (Mao et al., 2012b).

\subsection{PBM}

The diurnal variation of PBM could be identified in summer, but it was not apparent in winter despite the highest PBM mixing ratios (Fig. 8). Most sites showed a summertime diurnal pattern with higher values in daytime, and mixing ratios reached their daily maximum in the early afternoon, and lower mixing ratios at night. This indicated photochemical production or uptake from the gas phase during daytime. However, the Utah sites showed different diurnal patterns with the lowest values in the afternoon, similar to the GEM pattern in that area. UT97 showed lower PBM levels than Antelope Island (UT96), probably due to the elevated altitude of the sampling site. In general, the amplitude of diurnal variation of PBM was much smaller than that of GOM.

\section{Summary}

Speciated atmospheric mercury data collected at 11 AMNet sites were analyzed in detail for annual, seasonal, and diurnal variations. GEM mixing ratios at these sites were similar and comparable with the current background levels in the Northern Hemisphere. GEM exhibited seasonality with higher mixing ratios appearing in winter and spring and the lowest mixing ratios in fall. A similar diurnal pattern was found in several rural sites, whose lowest levels appeared in the early morning and maxima appeared at noon or in the early afternoon. GEM dissolution in dew at night was considered to be a dominant factor controlling this pattern (Mao and Talbot, 2012a).

The GOM mixing ratios appeared to be lower than many other GOM measurements around the world, but similar with some rural sites measurements in the US. AMNet data showed a large diversity of GOM values. The higher GOM median mixing ratios appeared in spring and summer, and the largest diurnal variations occurred in spring. The GOM diurnal fluctuation amplitudes for all seasons at most monitoring sites were in the range of 0 to 2 ppqv, except the especially larger amplitude at the Utah sites. The GOM mixing ratios at nighttime were much lower than in daytime.

The PBM mixing ratios at all coastal AMNet sites were lower than at inland sites. The influence of uptake of GEM and GOM by sea salt aerosols was not apparent, which may due to the deficiency of the PBM instrument to measure large aerosols. Diurnal variation of PBM can be found in summer instead of winter, albeit the amplitudes were lower than for GOM. High PBM mixing ratios appeared at daytime indicating photochemical production of PBM and uptake from the gas phase.

Acknowledgements. We thank the AMNet site operators (John Dalziel, Timothy Chang, Dirk Felton, Gary Conley, Larry Scrapper, Neil Olson, Eric Miller, Thomas Holsen) for providing the valuable atmospheric mercury data at all the observational sites. This work was supported by the Environmental Protection Agency under contract \#EP09H000355 and the National Oceanographic and Atmospheric Administration under grant \#NA07OAR4600514.

Edited by: R. Cohen

\section{References}

Amos, H. M., Jacob, D. J., Holmes, C. D., Fisher, J. A., Wang, Q., Yantosca, R. M., Corbitt, E. S., Galarneau, E., Rutter, A. P., Gustin, M. S., Steffen, A., Schauer, J. J., Graydon, J. A., Louis, V. L. St., Talbot, R. W., Edgerton, E. S., Zhang, Y., and Sunderland, E. M.: Gas-particle partitioning of atmospheric $\mathrm{Hg}(\mathrm{II})$ and its effect on global mercury deposition, Atmos. Chem. Phys., 12, 591-603, doi:10.5194/acp-12-591-2012, 2012.

Brunke, E. G., Labyschagne, C., and Slemr, F.: Gaseous mercury emissions from a fire in the Cape Peninsula, South Africa, during January 2000, Geophys. Res. Lett., 28, 1483-1496, 2001.

Calvert, J. G. and Lindberg, S. E.: Mechanisms of mercury removal by $\mathrm{O}_{3}$ and $\mathrm{OH}$ in the atmosphere, Atmos. Environ., 18, 33553367, 2005.

Choi, H.-D., Holsen, T. M., and Hopke, P. K.: Atmospheric mercury $(\mathrm{Hg})$ in the Adirondacks: Concentrations and sources, Environ. Sci. Technol., 42, 5644-5653, 2008.

Ebinghaus, R., Slemr, F., Brenninkmeijer, C. A. M., van Velthoven, P., Zahn, A., Hermann, M., O'Sullivan, D. A., and Oram, D. E.: Emissions of gaseous mercury from biomass burning in South America in 2005 observed during CARIBIC fights, Geophys. Res. Lett., 34, L08813, doi:10.1029/2006GL028866, 2007.

EPA (United States Environmental Protection Agency): Mercury Study Report to Congress, online available at: www.epa.gov/ mercury/report.html, 1997.

Feddersen, D. M., Talbot, R., Mao, H., and Sive, B. C.: Size distribution of atmospheric particulate mercury in marine and coastal atmospheres, Atmos. Chem. Phys. Discuss., 12, 14591-14621, doi:10.5194/acpd-12-14591-2012, 2012.

Friedli, H. R., Radke, L. F., and Lu, J. Y.: Mercury in smoke from biomass fires, Geophys. Res. Lett., 28, 3223-3226, 2001. 
Friedli, H. R., Radke, L. F., Lu, J. Y., Banic, C. M., Leaitch, W. R., and MacPherson, J. I.: Mercury emissions from burning of biomass from temperate North American forests: laboratory and airborne measurements, Atmos. Environ., 37, 253-267, 2003a.

Friedli, H. R., Radke, L. F., Prescott, R., Hobbs, P. V., and Sinha, P.: Mercury emissions from the August 2001 wildfires in Washington State and an agricultural waste fire in Oregon and atmospheric mercury budget estimates, Global Biogeochem. Cy., 17, 1039, doi:10.1029/2002GB001972, 2003b.

Friedli, H. R., Radke, L. F., Prescott, R., Li, P., Woo, J.-H., and Carmichael, G. R.: Mercury in the atmosphere around Japan, Korea, and China as observed during the 2001 ACE-Asia field campaign: Measurements, distributions, sources, and implications, J. Geophys. Res., 109, D19S25, doi:10.1029/2003JD004244, 2004.

Graydon, J. A., St. Louis, V. L., Lindberg, S. E., Hintelmann, H., and Krabbenhoft D. P.: Investigation of mercury exchange between forest canopy vegetation and the atmosphere using a new dynamic chamber, Environ. Sci. Technol., 40, 4680-4688, 2006.

Holmes, C. D., Jacob, D. J., and Yang, X.: Global lifetime of elemental mercury against oxidation by atomic bromine in the free troposphere, Geophys. Res. Lett., 33, L20808, doi:10.1029/2006GL027176, 2006.

Holmes, C. D., Jacob, D. J., Corbitt, E. S., Mao, J., Yang, X., Talbot, R., and Slemr, F.: Global atmospheric model for mercury including oxidation by bromine atoms, Atmos. Chem. Phys., 10, 12037-12057, doi:10.5194/acp-10-12037-2010, 2010.

Huang, J., Choi, H.-D., Hopke, P. K., and Holsen, T. M.: Ambient mercury sources inRochester, NY: results from Principle Components Analysis (PCA) of Mercury Monitoring Network Data. Environ. Sci. Technol., 44, 8441-8445, 2010.

Jaffe, D., Prestbo, E., Swartzendruber, P., Weiss-Penzias, P., Kato, S., Takami, A., Hatakeyama, S., and Kajii, Y.: Export of atmospheric mercury from Asia, Atmos. Environ., 39, 3029-3038, 2005.

Kellerhals, M., Beauchamp, S., Belzer, W., Blanchard, P.,Froude, F., Harvey, B., McDonald, K., Pilote, M., Poissant, L., Puckett, K., Schroeder, B., Steffen, A., and Tordon, R.: Temporal and spatial variability of total gaseous mercury in Canada: results from the Canadian Atmospheric Mercury Measurement Network (CAMNet), Atmos. Environ. 37, 1003-1011, 2003.

Kim, S. Y.: Continental outflow of polluted air from the U.S. to the North Atlantic and mercury chemical cycling in various atmospheric environments, $\mathrm{PhD}$ dissertation, University of New Hampshire, USA, 102, 2010.

Kock, H. H., Bieber, E., Ebinghaus, R., Spain, T. G., and Thees, B.: Comparison of long-term trends and seasonal variations of atmospheric mercury concentrations at the two European coastal monitoring stations Mace Head, Ireland and Zingst, Germany, Atmos. Environ., 39, 7549-7556, 2005.

Lai, Z. L., Talbot, R., Mao, H.: Recant decadal ozone trends at rural sites in New England, USA, submitted to Atmos. Chem. Phys., 2012.

Laurier, F. J. G., Mason, R. P., and Whalin, L.: Reactive gaseous mercury formation in the North Pacific Ocean's marine boundary layer: A potential role of halogen chemistry, J. Geophys. Res., 108, 4529, doi:10.1029/2003JD003625, 2003.

Laurier, F. and Mason, R.: Mercury concentration and speciation in the coastal and open ocean boundary layer, J. Geophys. Res., 112, D06302, doi:10.1029/2006JD007320, 2007.
Lindberg, S. E. and Stratton, W. J.: Atmospheric mercury speciation: concentrations and behavior of reactive gaseous mercury in ambient air, Environ. Sci. Technol. 32, 49-57, 1998.

Malcolm, E. G., Keeler, G. J., and Landis, M. S.: The effects of the coastal environment on the atmospheric mercury cycle, J. Geophys. Res., 108(D12), 4357, doi:10.1029/2002JD003084, 2003.

Mao, H., Talbot, R. W., Sigler, J. M., Sive, B. C., and Hegarty, J. D.: Seasonal and diurnal variations of $\mathrm{Hg}^{0}$ over New England, Atmos. Chem. Phys., 8, 1403-1421, doi:10.5194/acp-8-1403-2008, 2008.

Mao, H. and Talbot, R.: Speciated mercury at marine, coastal, and inland sites in New England - Part 1: Temporal variability, Atmos. Chem. Phys., 12, 5099-5112, doi:10.5194/acp-12-50992012, 2012a.

Mao, H., Talbot, R., Hegarty, J., and Koermer, J.: Speciated mercury at marine, coastal, and inland sites in New England - Part 2: Relationships with atmospheric physical parameters, Atmos. Chem. Phys., 12, 4181-4206, doi:10.5194/acp-12-4181-2012, 2012 b.

Nair, U. S., Wu, Y., Walters, J., Jansen, J., and Edgerton, E. S.: Diurnal and seasonal variation of mercury species at coastal-suburban, urban, and rural sites in the southeastern United States. Atmos. Environ., 47, 499-508, doi:10.1016/j.atmosenv.2011.09.056, 2012.

Obrist, D., Conen, F., Vogt, R., Siegwolf, R., and Alewell, C.: Estimation of $\mathrm{Hg}$ ! exchange between ecosystems and the atmosphere using ${ }^{222} \mathrm{Rn}$ and $\mathrm{Hg}^{0}$ concentration changes in the stable nocturnal boundary layer, Atmos. Environ., 40, 856-866, doi:10.1016/j.atmosenv.2005.10.012, 2006.

Pacyna, E. G. and Pacyna, J. M.: Global emission of mercury from anthropogenic sources in 1995, Water Air Soil Pollut., 137, 149$165,2002$.

Pacyna, E. G., Pacyna, J. M., Steenhuisen, F., and Wilson, S.: Global anthropogenic mercury emission inventory for 2000, Atmos. Environ., 40, 4048-4063, 2006.

Pacyna, E. G., Pacyna, J. M., Sundseth, K., Munthe, J., Kindbom, K., Wilson, S., Steenhuisen, F., and Maxson, P.: Global emission of mercury to the atmosphere from anthropogenic sources in 2005 and projections to 2020, Atmos. Environ., 44, 2487-2499, 2010.

Pal, B. and Ariya, P. A.: Studies of ozone initiated reactions of gaseous mercury: kinetics, product studies, and atmospheric implications, Phys. Chem. Chem. Phy., 6, 572-579, 2004a.

Pal, B. and Ariya, P. A.: Gas-phase $\mathrm{HO}^{\bullet}$-initiated reactions of elemental mercury: kinetics, product studies, and atmospheric implications, Environ. Sci. Technol., 38, 5555-5566, 2004b.

Peterson, C. and Gustin, M.: Mercury in the air, water and biota at the Great Salt Lake (Utah, USA), Sci. Total Environ., 405, 255268, 2008.

Peterson, C., Gustin, M., and Lyman, S.: Atmospheric mercury concentrations and speciation measured from 2004 to 2007 in Reno, Nevada, USA, Atmos. Environ., 43, 4646-4654, 2009.

Pirrone, N., Costa, P., Pacyna, J. M., and Ferrara, R.: Mercury emissions to the atmosphere from natural and anthropogenic sources in the Mediterranean region, Atmos. Environ., 35, 2997-3006, 2001.

Raofie, F. and Ariya, P. A.: Product study of the gas-phase BrOinitiated oxidation of $\mathrm{Hg} 0$ : evidence for stable $\mathrm{Hg} 1+$ compounds, Environ. Sci. Technol., 38, 4319-4326, 2004. 
Selin, N. E.: Global biogeochemical cycling of mercury: a review, Annu. Rev. Environ. Resourc., 34, 43-63, 2009.

Selin, N. E., Jacob, D. J., Park, R. J., Yantosca, R. M., Strode, S., Jaegle, L., and Jaffe D.: Chemical cycling and deposition of atmospheric mercury: Global constraints from observations, J. Geophys. Res., 112, D02308, doi:10.1029/2006JD007450, 2007.

Seigneur, C., Vijayaraghavan, K., Lohman, K., Karamchandani, P., and Scott, C.: Global source attribution for mercury deposition in the United States, Environ. Sci. Technol. 38, 555-569, 2004.

Seigneur, C., Vijayaraghavan, K., and Lohman, K.,: Atmospheric mercury chemistry: Sensitivity of global model simulations to chemical reactions, J. Geophys. Res., 111, D22306, doi:10.1029/2005JD006780, 2006.

Seinfeld, J. H. and Pandis, S. N.: Atmospheric Chemistry and Physics: from Air Pollution to Climate Change, John Wiley, New York, USA, 588-622, 2006.

Sigler, J. M., Lee, X., and Munger, W.: Emission and long-range transport of gaseous mercury from a large-scale Canadian boreal forest fire, Environ. Sci. Technol., 37, 4343-4347, 2003.

Sigler, J. M. and Lee, X.: Gaseous mercury in background forest soil in the northeastern United States, J. Geophys. Res., 111, G02007, doi:10.1029/2005JG000106, 2006.

Sigler, J. M., Mao, H., Sive, B. C., and Talbot, R.: Oceanic influence on atmospheric mercury at coastal and inland sites: a springtime noreaster in New England, Atmos. Chem. Phys., 9, 4023-4030, doi:10.5194/acp-9-4023-2009, 2009.

Sommar, J., Hallquist, M., Ljungstrom, E., and Lindqvist, O.: On the gas phase reactions between volatile biogenic mercury species and the nitrate radical, J. Atmos. Chem., 27, 233-247, 1997.

Sommar, J., Gardfeldt, K., Stromberg, D., and Feng, X.: A kinetic study of the gas-phase reaction between the hydroxyl radical and atomic mercury, Atmos. Environ., 35, 3049-3054, 2001.

Sprovieri, F., Pirrone, N., Gardfeldt., K., and Sommar, J.: Mercury speciation in the marine boundary layer along a $6000 \mathrm{~km}$ cruise path around the Mediterranean Sea, Atmos. Environ., 37, S6371, 21-39, 2003.

Sprovieri, F., Pirrone, N., Ebinghaus, R., Kock, H., and Dommergue, A.: A review of worldwide atmospheric mercury measurements, Atmos. Chem. Phys., 10, 8245-8265, doi:10.5194/acp10-8245-2010, 2010.

Strode, S. A., Jaegle, L., Jaffe, D. A., Swartzendruber, P. C., Selin, N. E., Holmes, C., and Yantosca, R. M.: TransPacific transport of mercury, J. Geophys. Res., 113, D15305, doi:10.1029/2007JD009428, 2008.

Stutz, J., Ackermann, R., Fast, J. D., and Barrie, L.: Atmospheric reactive chlorine and bromine at the Great Salt Lake, Utah, Geophys. Res. Lett., 29, 1380, doi:10.1029/2002GL014812, 2002.
Talbot R., Mao, H., and Sive, B.: Diurnal characteristics of surfacelevel $\mathrm{O}_{3}$ and other important trace gases in New England, J. Geophys. Res., 110, D09307, doi:10.1029/2004JD005449, 2005.

Talbot, R., Mao, H., Feddersen D., Smith, M., Kim, S.Y., Sive, B., Haase, K., Ambrose, J., Zhou, Y., and Russo, R.: Comparison of particulate mercury measured with manual and automated methods, Atmosphere, 2, 1-20, doi:10.3390/atmos2010001, 2011.

Temme, C., Blanchard, P., Steffen, A., Banic, C., Beauchamp, S., Poissant, L., Tordon, R., and Wiens, B.: Trend, seasonal and multivariate analysis study of total gaseous mercury data from the Canadian atmospheric mercury measurement network (CAMNet), Atmos. Environ., 41, 5423-5441, doi:10.1016/j.atmosenv.2007.02.021, 2007.

Valente, R. J., Shea, C., Humes, K. L., and Tanner, R. L.: Atmospheric mercury in the Great Smoky Mountains compared to regional and global levels, Atmos. Environ., 41, 1861-1873, 2007.

Wangberg, I., Munthe, J., Pirrone, N., Iverfeldt, A., Bahlman, E.,Costa, P., Ebinghaus, R., Feng, X., Ferrara, R., Gardfeldt, K., Kock, H., Lanzillotta, E., Mamane, Y., Mas, F., Melamed, E., Osnat, Y., Prestbo, E., Sommar, J., Schmolke, S., Spain, G., Sprovieri, F., and Tuncel, G.: Atmospheric mercury distribution in Northern Europe and in the Mediterranean region, Atmos. Environ., 35, 3019-3025, 2001.

Wang, Y., Huang, J., Zananski, T. J., Hopke, P. K., and Holsen, T. M.: Impacts of the Canadian Forest Fires on Atmospheric Mercury and Carbonaceous Particles in Northern New York, Environ. Sci. Technol., 44, 8435-8440, 2010.

Weiss-Penzias, P., Gustin, M. S., and Lyman, S. N.: Observations of speciated atmospheric mercury at three sites in Nevada: Evidence for a free tropospheric source of reactive gaseous mercury, J. Geophys. Res., 114, D14302, doi:10.1029/2008JD011607, 2009.

Weiss-Penzias, P., Jaffe, D. A., McClintick, A., Prestbo, E. M., and Landis, M. S.: Gaseous elemental mercury in the marine boundary layer: evidence for rapid removal in anthropogenic pollution. Environ. Sci. Technol., 37, 3755-3763, 2003.

Xin, M., Gustin, M., and Johnson, D.: Laboratory investigation of the potential for re-emission of atmospherically derived $\mathrm{Hg}$ from soils, Environ. Sci. Technol., 41, 4946-4951, 2007.

Yatavelli, R. L. N., Fahrni, J. K., Kim, M., Crist, K. C., Vickers, C. D., Winter, S. E., and Connell, D. P.: Mercury, $\mathrm{PM}_{2.5}$ and gaseous co-pollutants in the Ohio River Valley region: Preliminary results from the Athens supersite, Atmos. Environ., 40, 6650-6665, doi:10.1016/j.atmosenv.2006.05.072, 2006. 